\title{
Stabilization of [4Fe-4S] Ferredoxin Model Complex by a Combination of Hydrophobic Cholyl Group and the Specific NH $\cdots$ S Hydrogen Bond in Aqueous Micellar Solution
}

\author{
Norikazu Ueyama, ${ }^{\dagger}$ Masahiro Inohara, Takafumi Ueno, \\ Taka-aki OKamUra, and Akira NAKAMURA ${ }^{\dagger}$
}

Department of Macromolecular Science, Graduate School of Science, Osaka University, Osaka 560, Japan

(Received May 6, 1997)

KEY WORDS

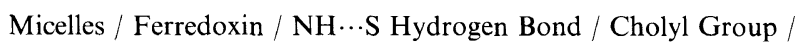

Ferredoxin $(\mathrm{Fd})$ in iron-sulfur proteins functions electron transfer in aqueous solution. Although various Fd model complexes have been synthesized, most of the model complexes are unstable in aqueous solution and in air. Water soluble $\mathrm{Fd}$ model complexes with water soluble thiolate ligand, e.g., $\left[\mathrm{Fe}_{4} \mathrm{~S}_{4}\left(\mathrm{SCH}_{2} \mathrm{CH}_{2} \mathrm{COO}\right)_{4}\right]^{6-}$, have been synthesized as models of native Fds. ${ }^{1,2}$ These complexes spontaneously decompose in an aqueous solution although a few reports have discussed on the stabilization of $\mathrm{Fd}$ model complexes having a synthetic bulky thiolate ligand in organic solvents. ${ }^{3-5} \mathrm{~A}$ Fd model complex has been synthesized using the cysteine residue in reduced bovine serum albumin or bovine insulin to be stabilized in aqueous solution. ${ }^{6}$ Inclusion of $[4 \mathrm{Fe}-4 \mathrm{~S}$ ] cluster in cyclodextrin thiolate ligand has been demonstrated to protect the hydrolysis in aqueous solution. ${ }^{7,8}$ The chemical simulation of the electron transfer has been demonstrated using cysteine-containing ferredoxin model complexes in aqueous micellar solutions. ${ }^{9}$ Tanaka and his coworkers reported a water soluble micelle system including adamantanethiolate or $p$-alkylarenethiolate Fd model complexes into a hydrophobic polymer detergent. ${ }^{10-12}$ Since these complexes are somewhat stable against water, an excess of thiolate ligand is still required in the process of the spectroscopic and electrochemical analysis under aqueous conditions. Thus, protection against water by the hydrophobic thiolate ligand has been ambiguously thought to be caused by the shielding of $\left[\mathrm{Fe}_{4} \mathrm{~S}_{4}(\mathrm{SR})_{4}\right]^{2-}$ core from water.

Intramolecular $\mathrm{NH} \cdots \mathrm{S}$ hydrogen bond has been found to shift the redox potential towards the positive side in

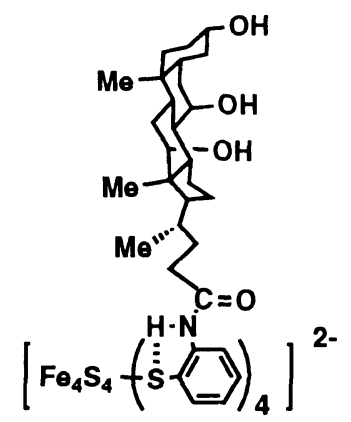

Scheme 1. $\left[\mathrm{Fe}_{4} \mathrm{~S}_{4}\left(\mathrm{~S} \text {-cholylNHC} \mathrm{H}_{6} \mathrm{H}_{4}\right)_{4}\right]^{2-}$.

\footnotetext{
† To whom correspondence should be addressed.
}

2-/1- and 3-/2-couples of $\left[\mathrm{Fe}_{4} \mathrm{~S}_{4}\left\{\mathrm{~S}-2,6-(t-\mathrm{BuCONH})_{2}-\right.\right.$ $\left.\left.\mathrm{C}_{6} \mathrm{H}_{3}\right\}_{2}\right]^{2-}$ in acetonitrile. ${ }^{13}$ Thus, the positive shift of the 2-/1-redox couple will contribute to the protection against dioxygen because of the stabilization of the 2-state as demonstrated in $\left[\mathrm{Fe}_{4} \mathrm{~S}_{4}\{\mathrm{~S}-2-\mathrm{RCONH}-6-\right.$ $\left.\left.\mathrm{PhC}_{6} \mathrm{H}_{3}\right\}_{4}\right]^{2-}$ due to the adjacent hydrophobic phenyl group. ${ }^{14}$ Unfortunately, these complexes do not provide a homogenous aqueous micellar solution because of their gradual crystallization in various aqueous micellar solutions.

The hydrophobic effect by still bulkier polycyclic hydrocarbyl group, cholyl group, is an interesting in this context. Thus, novel 2-cholylaminobenzenethiolate was examined as a hydrophobic thiolate ligand having $\mathrm{NH}$...S hydrogen bond to effectively include its Fd model complexes into aqueous micelles as shown in Figure 1.

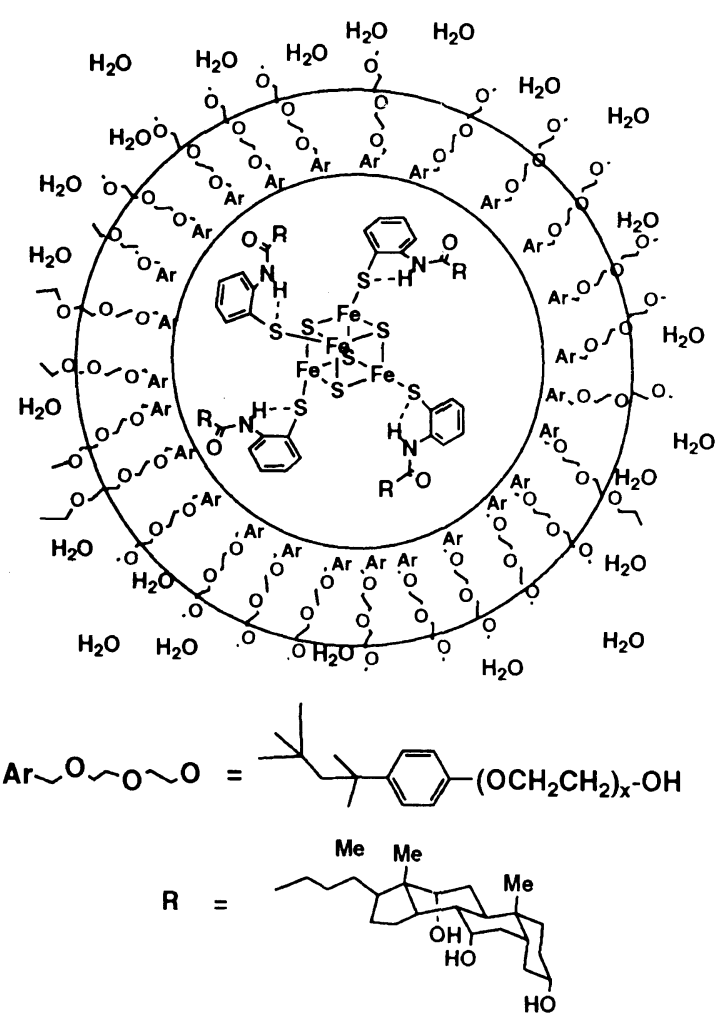

Figure 1. Schematic drawing of $[4 \mathrm{Fe}-4 \mathrm{~S}]$ model complex in aqueous micellar solution. 


\section{EXPERIMENTAL}

All procedures were performed in argon atmosphere by Schlenk technique.

\section{Materials}

All solvents were dried over calcium hydride and distilled under argon before use. $\left(\mathrm{Et}_{4} \mathrm{~N}\right)_{2}\left[\mathrm{Fe}_{4} \mathrm{~S}_{4}(\mathrm{~S}-2-t\right.$ $\left.\left.\mathrm{BuCONHC}_{6} \mathrm{H}_{4}\right)_{4}\right]$ and $\left(\mathrm{Et}_{4} \mathrm{~N}\right)_{2}\left[\mathrm{Fe}_{4} \mathrm{~S}_{4}\{\mathrm{~S}-2,6-(t-\right.$ $\left.\left.\mathrm{BuCONH})_{2} \mathrm{C}_{6} \mathrm{H}_{3}\right\}_{4}\right]$ were synthesized by the same method reported in the previous paper. ${ }^{13}$ The synthesis of disulfide, $\left\{\mathrm{S}-2 \text {-cholylNHC} \mathrm{NH}_{6} \mathrm{H}_{4}\right\}_{2}$, will be reported elsewhere. ${ }^{15}$

$\left[\left(\mathrm{Et}_{4} \mathrm{~N}\right)_{2}\left[\mathrm{Fe}_{4} \mathrm{~S}_{4}\left(\mathrm{~S}\right.\right.\right.$-2-cholylNHC $\left.\mathrm{CH}_{6} \mathrm{H}_{4}\right]$ (1) The complex was synthesized by a ligand exchange method. A mixture of $\left(\mathrm{NEt}_{4}\right)_{2}\left[\mathrm{Fe}_{4} \mathrm{~S}_{4}(\mathrm{SPh})_{4}\right]\left(65 \mathrm{mg}, 4.4 \times 10^{-5}\right.$ $\mathrm{mol})$ in acetonitrile $(10 \mathrm{ml})$ and bis $(2$-cholylaminophenyl) disulfide $\left(126 \mathrm{mg}, 1.2 \times 10^{-4} \mathrm{~mol}\right)$ in tetrahydrofuran (THF) $(5 \mathrm{ml})$ was stirred at room temperature overnight. The solution was concentrated under reduced pressure. The black crude product was washed with diethyl ether and reprecipitated from acetonitrile/diethyl ether to give black powder in $38 \%$ yield. ${ }^{1} \mathrm{H}$ NMR (acetonitrile- $d_{3}$ ) 9.25 (s $4 \mathrm{H}), 8.37$ (s $4 \mathrm{H}), 7.81$ (s $4 \mathrm{H}), 6.58$ (s $4 \mathrm{H}), 5.83$ (s $4 \mathrm{H}), 3.88(\mathrm{~s} 4 \mathrm{H}), 3.69$ (s $4 \mathrm{H})$. Mass spectrum for ${ }^{54} \mathrm{Fe}$ $m / z,\left[\mathrm{M}-2\left(\mathrm{NEt}_{4}\right)^{+}\right]^{2-}=1205$ (Calcd 1204.4). The elemental analysis of $\mathbf{1}$ indicated a large amount of contaminants, water and acetonitrile, which were detected by the ${ }^{1} \mathrm{H}$ NMR and mass spectra.

\section{Triton X-100 Aqueous Micellar Solution}

$\left(\mathrm{Et}_{4} \mathrm{~N}\right)_{2}\left[\mathrm{Fe}_{4} \mathrm{~S}_{4}\left(\mathrm{~S}-2 \text {-cholylNHC }{ }_{6} \mathrm{H}_{4}\right)_{4}\right](8.4 \mathrm{mg}, 3.1 \times$ $10^{-6} \mathrm{~mol}$ ) was dissolved in a small amount of THF. To the solution was added $0.13 \mathrm{ml}$ of Triton X-100 (Nacalai Tesque) and concentrated under reduced pressure. The obtained viscous oil was diluted with $1.1 \mathrm{ml}$ of water to give a homogeneous $2.5 \mathrm{mM}$ aqueous micellar solution at $\mathrm{pH}$ 7.6. Similarly, a $0.5 \mathrm{mM}$ solution was prepared at $\mathrm{pH} 7.5$.

\section{Oxidation of 1 by Dioxygen}

Aqueous micellar solution $(0.3 \mathrm{ml})$ of $\left(\mathrm{NEt}_{4}\right)_{2}\left[\mathrm{Fe}_{4} \mathrm{~S}_{4^{-}}\right.$ $\left.(\mathrm{SAr})_{4}\right] \quad\left(\mathrm{SAr}=\mathrm{S}-2-\right.$ cholyl- $\mathrm{C}_{6} \mathrm{H}_{4}, \mathrm{~S}-2,6-(t-\mathrm{BuCONH})_{2}-$ $\mathrm{C}_{6} \mathrm{H}_{3}, \mathrm{~S}-2-t-\mathrm{BuCONHC}_{6} \mathrm{H}_{4}$ ) was bubbled with $1 \mathrm{ml}$ of dioxygen $\left(4.5 \times 10^{-5} \mathrm{~mol}\right)$ in $1 \mathrm{~mm}$ cell at room temperature. The reaction was followed by the absorbance at $450 \mathrm{~nm}$ for $60 \mathrm{~min}$ using UV-visible spectroscopy. Since excess dioxygen ( $45 \mathrm{eq}$ ) was added to complex 1 , the concentration of dioxygen was approximately constant during the oxidation. Then the reaction proceeds with a pseudo-1st order rate constant $\left(k_{\text {obs }}^{\prime}\right)$ as the following equation,

$$
\ln [\mathrm{I}] /[\mathrm{I}]_{0}=-k_{\mathrm{obs}}^{\prime} t
$$

\section{Physical Measurements}

Absorption spectra were recorded on a JASCO Ubest-30 spectrometer in units of $\mathrm{M}^{-1} \mathrm{~cm}^{-1} .{ }^{1} \mathrm{H}$ NMR spectra were obtained with a Jeol EX-270 in acetonitrile$d_{3}$ at $30^{\circ} \mathrm{C}$. The measurements of cyclic voltammograms in acetonitrile solution or in aqueous micellar solution were carried out on a Yanaco P-1100 instrument with a three-electrode system: a glassy carbon working elec- trode, a Pt-wire auxiliary electrode and a saturated calomel electrode (SCE). The scan rate was $100 \mathrm{mV} \mathrm{s}^{-1}$. Concentration of sample was about $2.5 \mathrm{mM}$, containing $0.1 \mathrm{M}$ of $\left(n-\mathrm{Bu}_{4} \mathrm{~N}\right) \mathrm{ClO}_{4}$ (or $\mathrm{NEt}_{4} \mathrm{Cl}$ in aqueous micellar solution) as a supporting electrolyte. ESI-MS analyses were performed in a solution with a PE-Sciex API-III plus mass spectrometer which was operated in a negative ion mode. Sample solutions were infused through the

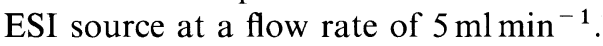

\section{RESULTS AND DISCUSSION}

\section{Synthesis}

The $[4 \mathrm{Fe}-4 \mathrm{~S}] \mathrm{Fd}$ model complex, $\left(\mathrm{Et}_{4} \mathrm{~N}\right)_{2}\left[\mathrm{Fe}_{4} \mathrm{~S}_{4}(\mathrm{~S}-2-\right.$ cholyl $\left.\left.\mathrm{NHC}_{6} \mathrm{H}_{4}\right)_{4}\right]$ (1), was synthesized by the ligand exchange reaction between $\left(\mathrm{NEt}_{4}\right)_{2}\left[\mathrm{Fe}_{4} \mathrm{~S}_{4}(\mathrm{SPh})_{4}\right]$ and disulfide, $\left\{\mathrm{S} \text {-2-cholyl } \mathrm{NHC}_{6} \mathrm{H}_{4}\right\}_{2}$, in acetonitrile under $\mathrm{Ar}$ atmosphere at room temperature. ${ }^{13}$

$$
\begin{aligned}
& \left(\mathrm{NEt}_{4}\right)_{2}\left[\mathrm{Fe}_{4} \mathrm{~S}_{4}(\mathrm{SPh})_{4}\right]+2 \mathrm{ArSSAr} \frac{\text { under } \mathrm{Ar}}{\text { in } \mathrm{CH}_{3} \mathrm{CN}} \\
& \left(\mathrm{NEt}_{4}\right)_{2}\left[\mathrm{Fe}_{4} \mathrm{~S}_{4}(\mathrm{SAr})_{4}\right]+2 \mathrm{PhSSPh} \\
& (\mathrm{SAr}=2 \text {-cholylaminobenzenethiolate })
\end{aligned}
$$

This exchange quantitatively proceeds because of difference in the acidity between PhSH and 2-cholylaminobenzenethiol. ${ }^{16}$

\section{Enhanced Stability of $\mathbf{1}$ towards Hydrolytic Degradation in Aqueous Micellar Solution}

Figure 2 shows the UV-visible spectra of $\mathbf{1}$ in acetonitrile and in an aqueous $2.5 \mathrm{mM}$ Triton X-100 micellar solution under Ar atmosphere at room tem perature. A clear shoulder at $450 \mathrm{~nm}$ due to the characteristic absorption for arenethiolate $\mathrm{Fd}$ model complexes was observed in both solutions and maintained over one week. Thus, [4Fe-4S] core having the $\mathrm{NH} \cdots \mathrm{S}$ hydrogen bond in $\mathbf{1}$ is extremely stabilized under $\mathrm{Ar}$ atmosphere even in the aqueous Triton X-100 solution. Such an enhanced stability against hydrolysis is due to the prevention of dissociation of the thiolate ligand from Fe ion by the $\mathrm{NH} \cdots \mathrm{S}$ hydrogen bond as demonstrated for the ligand exchange reaction between $\left(\mathrm{Et}_{4} \mathrm{~N}\right)_{2}\left[\mathrm{Fe}_{4} \mathrm{~S}_{4}(\mathrm{~S}\right.$ 2-t-BuCONHC$\left.\left.{ }_{6} \mathrm{H}_{4}\right)_{4}\right]$ and excess PhSH. ${ }^{13}$ Actually, the addition of thiophenol (10 equiv) does not change the absorption spectrum in an aqueous micellar solution.

\section{Protection of $[4 \mathrm{Fe}-4 \mathrm{~S}]$ Core from the Oxidative Degrada- tion by Dioxygen in Aqueous Micellar Solution}

The redox potential of $\mathbf{1}$ was determined by the cyclic voltammgrams and the complex exhibits a $\left[\mathrm{Fe}_{4} \mathrm{~S}_{4}\right.$ $\left.(\mathrm{SAr})_{4}\right]^{3-} /\left[\mathrm{Fe}_{4} \mathrm{~S}_{4}(\mathrm{SAr})_{4}\right]^{2-}$ couple at $-0.92 \mathrm{~V}$ (vs. SCE) in acetonitrile and at the same $-0.92 \mathrm{~V}$ in an aqueous $2.5 \mathrm{mM}$ Triton X-100 solution. A slight shift of the redox potential by $\mathrm{NH} \cdots \mathrm{S}$ hydrogen bond between organic solvent and aqueous micellar solution indicates that the hydrophobic cholyl group supports the $\mathrm{NH}$... S hydrogen bond in the aqueous micellar solution as illustrated in Figure 1 .

On the other hand, an oxidation potential for $\left[\mathrm{Fe}_{4} \mathrm{~S}_{4}(\mathrm{SAr})_{4}\right]^{2-} /\left[\mathrm{Fe}_{4} \mathrm{~S}_{4}(\mathrm{SAr})_{4}\right]^{1-}$ in 1 was observed at $+0.1 \mathrm{~V}$ indicating the shift of the 2-/1-redox potential. The shift of the oxidation potential over $+0.1 \mathrm{~V}$ de- 


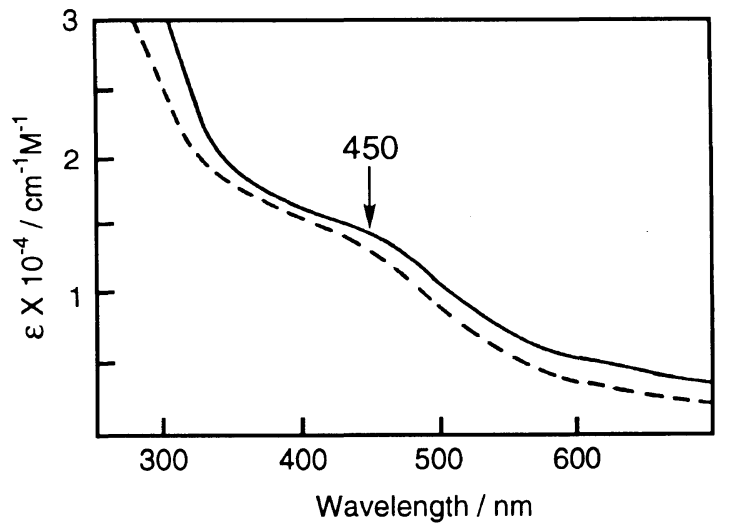

Figure 2. UV-visible spectra of $\left(\mathrm{Et}_{4} \mathrm{~N}\right)_{2}\left[\mathrm{Fe}_{4} \mathrm{~S}_{4}(\mathrm{~S}\right.$-2-cholylNH$\left.\left.\mathrm{C}_{6} \mathrm{H}_{4}\right)_{4}\right](1)$ in aqueous $2.5 \mathrm{mM}$ Triton X-100 micellar solution ( - ) at $\mathrm{pH} 7.6$ and in $\mathrm{MeCN}(--)$.

Table I. The observed oxidation rates of $\left(\mathrm{Et}_{4} \mathrm{~N}\right)_{2}\left[\mathrm{Fe}_{4} \mathrm{~S}_{4}\left(\mathrm{~S}-2 \text {-cholylNHC }{ }_{6} \mathrm{H}_{4}\right)_{4}\right](\mathbf{1})$, (Et64N)2[Fe $\left.\mathrm{F}_{4}\left(\mathrm{~S}-2-t-\mathrm{BuCONHC}_{6} \mathrm{H}_{4}\right)_{4}\right]$ and $\left(\mathrm{Et}_{4} \mathrm{~N}\right)_{2}\left[\mathrm{Fe}_{4} \mathrm{~S}_{4}\left(\mathrm{~S}-2,6-(t-\mathrm{BuCONH})_{2} \mathrm{C}_{6} \mathrm{H}_{3}\right)_{4}\right]$ in THF and in aqueous $2.5 \mathrm{mM}$ Triton $\mathrm{X}-100$ micellar solution at $\mathrm{pH} 7.6$

\begin{tabular}{|c|c|c|}
\hline \multirow[b]{2}{*}{ Fd model complexes } & \multicolumn{2}{|c|}{$k_{\mathrm{obs}}^{\prime} / \mathrm{s}^{-1}$} \\
\hline & In THF & $\begin{array}{l}\text { In micellar } \\
\text { solution }\end{array}$ \\
\hline$\left(\mathrm{Et}_{4} \mathrm{~N}\right)_{2}\left[\mathrm{Fe}_{4} \mathrm{~S}_{4}\left(\mathrm{~S}-2 \text {-cholylNH-C }{ }_{6} \mathrm{H}_{4}\right)_{4}\right]$ & 0.77 & 0.29 \\
\hline$\left(\mathrm{Et}_{4} \mathrm{~N}\right)_{2}\left[\mathrm{Fe}_{4} \mathrm{~S}_{4}\left(\mathrm{~S}-2-t-\mathrm{BuCONH}-\mathrm{C}_{6} \mathrm{H}_{4}\right)_{4}\right]$ & 0.46 & 0.37 \\
\hline$\left(\mathrm{Et}_{4} \mathrm{~N}\right)_{2}\left[\mathrm{Fe}_{4} \mathrm{~S}_{4}\left(\mathrm{~S}-2,6-(t-\mathrm{BuCONH})_{2} \mathrm{C}_{6} \mathrm{H}_{3}\right)_{4}\right]$ & 1.5 & 0.57 \\
\hline
\end{tabular}

creases the oxidation rate for these complexes by dioxygen. The rates of the oxidation by dioxygen for $\mathbf{1}$, $\left(\mathrm{Et}_{4} \mathrm{~N}\right)_{2}\left[\mathrm{Fe}_{4} \mathrm{~S}_{4}\left(\mathrm{~S}-2-t-\mathrm{BuCONHC}_{6} \mathrm{H}_{4}\right)_{4}\right]$ and $\left(\mathrm{Et}_{4} \mathrm{~N}\right)_{2}-$ $\left[\mathrm{Fe}_{4} \mathrm{~S}_{4}\left\{\mathrm{~S}-2,6-(t-\mathrm{BuCONH})_{2} \mathrm{C}_{6} \mathrm{H}_{3}\right\}_{4}\right]$ were determined in $\mathrm{THF}$ at room temperature. The data obtained by the UV-visible spectra and cyclic voltammograms indicate that the oxidized (1-) state is unstable and decomposed instantly. The NH...S hydrogen bond does not contribute to the stability of the (1-) state of [4Fe-4S] core under aerobic conditions.

The oxidation rate with dioxygen was monitored by the characteristic absorption at $450 \mathrm{~nm}$ due to the ligand-to-metal charge transfer band of the [4Fe-4S] core in acetonitrile at room temperature. The reaction was analyzed as a pseudo first-order kinetic. The observed reaction rate $\left(k_{\mathrm{obs}}^{\prime}\right)$ was obtained in acetonitrile and in $10 \%$ aqueous Triton X-100 solution as listed in Table I. The observed oxidation rates $\left(0.29\right.$ and $\left.0.57 \mathrm{~s}^{-1}\right)$ in micellar solution for 1 and $\left(\mathrm{Et}_{4} \mathrm{~N}\right)_{2}\left[\mathrm{Fe}_{4} \mathrm{~S}_{4}\{\mathrm{~S}-2,6-(t-\right.$ $\left.\left.\mathrm{BuCONH})_{2} \mathrm{C}_{6} \mathrm{H}_{3}\right\}_{4}\right]$, respectively, are smaller than those $\left(0.77\right.$ and $\left.1.5 \mathrm{~s}^{-1}\right)$ in acetonitrile. The $[4 \mathrm{Fe}-4 \mathrm{~S}]$ core in both complexes is stabilized in aqueous micellar so- lution. On the other hand, $\left(\mathrm{Et}_{4} \mathrm{~N}\right)_{2}\left[\mathrm{Fe}_{4} \mathrm{~S}_{4}(\mathrm{~S}-2-t\right.$-Bu$\left.\left.\mathrm{CONHC}_{6} \mathrm{H}_{4}\right)_{4}\right]$ gives similar rates $\left(0.46\right.$ and $\left.0.37 \mathrm{~s}^{-1}\right)$ in THF and in micellar solution, respectively. Increase in the number of NH...S hydrogen bond destabilizes the [4Fe-4S] core against dioxygen in THF, but it stabilizes in aqueous micellar solution as seen in $\left(\mathrm{Et}_{4} \mathrm{~N}\right)_{2} \mathrm{CFe}_{4} \mathrm{~S}_{4}-$ $\left.\left(\mathrm{S}-2-t-\mathrm{BuCONHC}{ }_{6} \mathrm{H}_{4}\right)_{4}\right]$ and $\left(\mathrm{Et}_{4} \mathrm{~N}\right)_{2}\left[\mathrm{Fe}_{4} \mathrm{~S}_{4}(\mathrm{~S}-2,6-(t-\right.$ $\left.\left.\mathrm{BuCONH})_{2} \mathrm{C}_{6} \mathrm{H}_{3}\right)_{4}\right]$. Thus, the hydrophobic cholyl group supports the formation of the $\mathrm{NH}$... S hydrogen bond which decreases the oxidation rate by the positive shift of the 2-/1-redox potential.

\section{Conclusion}

Simple thiolate Fd model complexes are unstable against hydrolysis and air, whereas native $\mathrm{Fd}$ proteins has a stable $[4 \mathrm{Fe}-4 \mathrm{~S}]$ core in the protein. Our model complex 1 having a hydrophobic cholylamide group and specific $\mathrm{NH} \cdots \mathrm{S}$ hydrogen bond shows a remarkable stabilization in aqueous micellar solution. The $\mathrm{NH} \cdots \mathrm{S}$ hydrogen bond contributes to the positive shift of the 2-/1-redox potential which leads to weaker reactivity toward dioxygen. Furthermore, the hydrogen bond prevents the hydrolysis with the low $\mathrm{p} K_{\mathrm{a}}$ value of the thiolate at the conjugate acid form. As expected the hydrophobic environments also protect the $[4 \mathrm{Fe}-4 \mathrm{~S}]$ core from hydrolysis and oxidation.

\section{REFERENCES}

1. R. C. Job and T. C. Bruice, Proc. Natl. Acad. Sci. U.S.A., 72, 2478 (1975)

2. C. L. Hill, J. Renaud, R. H. Holm, and L. E. Mortenson, J. Am. Chem. Soc., 99, 2549 (1977).

3. M. Millar, J. F. Lee, S. A. Koch, and R. Fikar, Inorg. Chem., 21, 4105 (1982).

4. N. Ueyama, T. Sugawara, M. Fuji, A. Nakamura, and N. Yasuoka, Chem. Lett., 175 (1985).

5. Y. Okuno, K. Uoto, O. Yonemitsu, and T. Tomohiro, J. Chem. Soc., Chem. Commun., 1018 (1987).

6. B. Odell and P. J. Geary, J. Chem. Soc., Dalton Trans., 29 (1984).

7. B. Siegel, Inorg. Nucl. Chem., 41, 609 (1979).

8. Y. Kuroda, Y. Sasaki, Y. Shiroiwa, and I. Tabushi, J. Am. Chem. Soc., 110, 4049 (1988)

9. I. Tabushi, Y. Kuroda, and Y. Sasaki, Tetrahedron, 44, 2843 (1988).

10. M. Nakamoto, K. Tanaka, and T. Tanaka, J. Chem. Soc., Chem. Commun., 1422 (1988).

11. . Nakamoto, K. Tanaka, and T. Tanaka, Bull. Chem. Soc. Jpn., 61, 4099 (1988).

12. K. Tanaka, M. Moriya, and T. Tanaka, Inorg. Chem., 25, 835 (1986).

13. N. Ueyama, Y. Yamada, T. Okamura, S. Kimura, and A. Nakamura, Inorg. Chem., 35, 6473 (1996).

14. T. Ueno, N. Ueyama, and A. Nakamura, J. Chem. Soc., Dalton Trans., 3859 (1996).

15. N. Ueyama, M. Inohara, T. Ueno, T. Okamura, and A. Nakamura, to be submitted.

16. L. Que Jr., M. A. Bobrik, J. A. Ibers, and R. H. Holm, J. Am. Chem. Soc., 96, 4168 (1974). 